\title{
Cytomegalovirus Infection Enhances Smooth Muscle Cell Proliferation and Intimal Thickening of Rat Aortic Allografts
}

Karl B. Lemström, ${ }^{\star}$ Johan H. Bruning, ${ }^{\star}$ Cathrien A. Bruggeman, ${ }^{\star}$ Irmeli T. Lautenschlager, ${ }^{*}$ and Pekka J. Hăyry * From *Transplantation Laboratory, SF-00014 University of Helsinki, Finland; and ${ }^{\ddagger}$ Department of Medical Microbiology, University of Limburg, 6202 AZ Maastricht, The Netherlands

\begin{abstract}
Inbred DA (AG-B4, RT1 ${ }^{2}$ ) and WF (AG-B2, RT1 ${ }^{\text {v }}$ ) rats were used as donors and recipients of aortic allografts. The recipient rats were inoculated i.p. either on day 1 (early infection) or on day 60 (late infection) with $10^{5}$ plaque-forming units of rat cytomegalovirus (RCMV). The control rats were left noninfected. The presence of viral infection was demonstrated by plaque assays from biopsies of the salivary glands, liver, and spleen at sacrifice. The rats received $300 \mu \mathrm{Ci}\left[{ }^{3} \mathrm{H}\right.$ ] thymidine by i.v. injection $3 \mathrm{~h}$ before sacrifice, and the grafts were removed at various time points for histology, immunohistochemistry, and autoradiography. RCMV infection significantly enhanced the generation of allograft arteriosclerosis. Infection at the time of transplantation had two important effects. First, the infection was associated with an early, prominent inflammatory episode and proliferation of inflammatory cells in the allograft adventitia. Second, the viral infection doubled the proliferation rate of smooth muscle cells and the arteriosclerotic alterations in the intima. In late infection the impact of RCMV infection on the allograft histology was nearly nonexistent. RCMV infection showed no effect in syngeneic grafts. These results suggest that early infection is more important to the generation of accelerated allograft arteriosclerosis than late infection, and that an acute alloimmune response must be associated with virus infection, to induce accelerated allograft arteriosclerosis. RCMVinfected aortic allografts, as described here, provide the first experimental model to investigate the interaction between the virus and the vascular wall of the transplant. (J. Clin. Invest. 1993. 92:549-558.) Key words: chronic rejection • cytomegalovirus $\cdot$ heart $\bullet$ transplantation
\end{abstract}

\section{Introduction}

Cardiac transplantation is the only method currently available to return patients with end-stage heart disease to normal life. Within the past decade, short-term survival rates after heart transplantation have impressively improved, the 1-yr survival rate now being $85 \%$. Despite the substantial improvement in early survival, the percentage of late death has not significantly reduced (1).

Address reprint requests to Dr. Karl Lemström, Transplantation Laboratory, POB 21 (Haartmaninkatu 3), SF-00014 University of Helsinki, Finland.

Received for publication 17 December 1992 and in revised form 2 March 1993.

J. Clin. Invest

(C) The American Society for Clinical Investigation, Inc.

$0021-9738 / 93 / 08 / 0549 / 10 \quad \$ 2.00$

Volume 92, August 1993, 549-558
Accelerated allograft arteriosclerosis, i.e., chronic rejection, has emerged as a major factor affecting cardiac allograft survival in the long run $(2,3)$. It is the main cause of death after the first posttransplant year. In coronary angiography, the incidence of cardiac allograft arteriosclerosis is between $6 \%$ and $18 \%$ at $1 \mathrm{yr}, 23 \%$ at $2 \mathrm{yr}$, and $50 \%$ at $5 \mathrm{yr}(4,5)$, with angiographic underestimation of this disorder in some patients (6). This phenomenon is probably due to several risk factors, such as humoral and cellular immune injury, hyperlipidemia, and infections $(7-10)$.

Cytomegalovirus (CMV) ${ }^{1}$ infection is an important cause of morbidity and mortality among heart allograft recipients (11). There is also strong clinical evidence indicating the role of CMV infection in the pathogenesis of cardiac allograft arteriosclerosis (12-14). In addition, CMV nucleic acids have been identified in the coronary arteries of heart transplant recipients with severe accelerated allograft arteriosclerosis (15). Furthermore, the possible role of herpesviruses (16), in particular CMV (17-19), in the pathogenesis of classical atherosclerosis has been substantiated in recent studies (20).

As of now, no experimental animal model has been available to investigate the pathophysiology of CMV infection in the vascular wall of the transplant. Nonimmunosuppressed aortic allografts exchanged between major and minor histoincompatible rat strains develop, with time, arteriosclerotic alterations which are virtually indistinguishable from those observed during chronic cardiac rejection in humans (21). In this article we describe the first experimental animal model to study the pathophysiology of virus infection in the vascular wall of the transplant, by demonstrating that rat CMV (RCMV) infection $(22,23)$ significantly enhances experimental allograft arteriosclerosis.

\section{Methods}

Experimental animals. Inbred DA (AG-B4, RT $1^{\mathrm{a}}$ ) and WF (AG-B2, $R T 1^{v}$ ) rat strains were used as donors and recipients, respectively. The animals were purchased from the Zentralinstitut für Versuchstierzucht (Hannover, FRG). They were 2-3 mo of age, and weighed 200-300 g. The rats were fed with regular rat food (altromin, Standard Diot, $\mathrm{Chr}$. Petersen A/S, Ringsted, Denmark), and water ad libitum.

All animals received humane care in compliance with the Principles of Laboratory Animal Care and the Guide for the Care and Use of Laboratory Animals prepared and formulated by the Institute of Laboratory Animal Resources and published by the National Institutes of Health (NIH Publication No. 86-23, revised 1985).

Heterotopic aortic allografts. An approximately 3-cm-long segment of descending thoracic aorta was removed, thoroughly perfused with PBS, and used as a transplant as described previously (21). End-to-end

1. Abbreviations used in this paper: CMV, cytomegalovirus; IP, immunoperoxidase; LCA, leukocyte common antigen; PSU, point score unit; RCMV, rat CMV. 
anastomosis was performed using 9-0 continuous nylon suture. The graft was transplanted into heterotopic position below renal arteries and above bifurcation, forming a loop in the recipient abdominal cavity. Total ischemic time varied from 45 to $60 \mathrm{~min}$, during which time the graft was kept in an ice bath of $+4^{\circ} \mathrm{C}$ for $15 \mathrm{~min}$. The animals were anaesthetized with choral hydrate $240 \mathrm{mg} / \mathrm{kg}$ i.p., and were given 0.25 $\mathrm{mg} / \mathrm{kg}$ buprenorphine s.c. (Temgesic; Reckitt \& Colman, Hull, UK) for postoperative pain relief. Strain combinations DA to DA and DA to WF were used for syngeneic and allogeneic transplantations, respectively. The grafts were removed at 7 and $14 \mathrm{~d}$, and 1,3 , and 6 mo after transplantation in the early infection group, and at 7 and $14 \mathrm{~d}$, and 1 and $4 \mathrm{mo}$ after infection in the late infection group (see below). The control rats were killed at 7 and $14 \mathrm{~d}$, and 1, 2, 3, 6, and 12 mo after transplantation. Usually five successful transplantations were included in each time point. All grafts were processed for histology and autoradiography.

$R C M V$. RCMV Maastricht strain $(22,23)$ was passaged by infecting rat embryo fibroblasts, prepared from 17-d-old DA rat embryos. The cells were cultured in flasks containing modified Eagle's MEM (Flow Laboratories, Irvine, UK) supplemented with $200 \mathrm{mM}$ L-glutamine (Northumbria Biologicals Ltd., Cramlington, UK), 10,000 IU/ $\mathrm{ml}$ penicillin $/ 1,000 \mu \mathrm{g} / \mathrm{ml}$ streptomycin solution (Gibco Ltd., Paisley, UK) and 2\% FCS (Gibco Ltd.) according to standard viral culture techniques (24). The stocks of virus were stored at $-70^{\circ} \mathrm{C}$ until use.

$R C M V$ infection in the transplant recipient. Recipient rats were inoculated i.p. with $10^{5}$ plaque-forming units (PFU) of RCMV either on the 1st posttransplant day (early infection group), or on the 60th posttransplant day (late infection group). The control rats were left noninfected. The infected and noninfected rats were kept in separate colonies with otherwise similar diet and conditions.

Plaque assays for the quantitation of viral stock. Quantitation of infectious virus was done by plaque assays, using a modification of the method described by Wentworth and French (25), and Bruggeman et al. (22). Confluent rat embryo fibroblast cell monolayers were infected with $200 \mu \mathrm{l}$ of the appropriate virus dilution and incubated for $90 \mathrm{~min}$ at $37^{\circ} \mathrm{C}$ in a $5 \% \mathrm{CO}_{2}$ incubator. After the incubation, infected cells were covered with $1 \mathrm{ml}$ of DME (Biological Industries, Kibbutz Beth, Haemek, Israel) with final concentration of $0.25 \%$ agar (Bacto-Agar, Difco, Inc., Detroit, MI). After an incubation of $7 \mathrm{~d}$ the cells were fixed with $10 \%$ formaline for one night at room temperature. After the fixation, the solid base layer was removed, the cell monolayers were stained with $1 \%$ aqueous crystal violet, and the plaques were counted.

Plaque assay for the demonstration of RCMV infection. The biopsies from salivary glands, liver, and spleen were taken aseptically in culture medium (as above) at sacrifice, and stored at $-70^{\circ} \mathrm{C}$ for plaque assays. In short, organs were homogenized in a tissue grinder and suspended in MEM with 2\% FCS. Quantitation of infectious virus was done by plaque assays as described (22). For this purpose 10-fold dilutions of $10 \%$ homogenates ( $\mathrm{wt} / \mathrm{vol}$ ) were inoculated on confluent rat embryo fibroblast monolayers. After an incubation of $7 \mathrm{~d}$, the number of plaques was monitored microscopically after methylene blue staining.

Immunoperoxidase staining for RCMV antigen detection. Formaline-fixed paraffin sections, $4 \mu \mathrm{m}$ thick, were stained with monoclonal antibodies, directed against early and late antigens of the virus, to detect RCMV antigens in the vascular wall $(26,27)$.

Histological specimens and staining. A segment of the graft was fixed in $10 \%$ buffered formaline, embedded in paraffin, and examined histologically after sectioning and staining with Mayer's hematoxylineosin. Cross sections were prepared for evaluation of circular changes in the graft. Aortas of nontransplanted rats and thoracic aortas of the recipients were used as controls. There was no difference, whether in situ fixation was performed or not.

Quantitation of histology in rat aortic transplants. The morphological changes were quantitated according to standard morphometric principles (28), and are expressed as point score units (PSU), i.e., mean number of points falling over a given anatomical area using straight, cross-sectional lines, and a $0.02-\mathrm{mm}$ grid. The number of cell nuclei and the thickness in the different layers of aorta, i.e., adventitia, media, and intima, separated from each other by intimal and external elastic lamina, were evaluated. The mean $( \pm \mathrm{SEM})$ was used as final scores.

In vivo labeling and autoradiography. All rats received $300 \mu \mathrm{Ci}$ of [methyl $\left.-{ }^{3} \mathrm{H}\right]$ thymidine $\left(\left[{ }^{3} \mathrm{H}\right] \mathrm{TdR} ;\right.$ Amersham International plc, Amersham, UK) by i.v. injection via dorsalis penis (males) or femoralis (females) vein $3 \mathrm{~h}$ before sacrifice. The histology was processed from paraffin sections, emulsion film autoradiography (Ilford L.4; Ilford, Mobberley, Cheshire, UK) was performed, and the labeling of the adventitial, media, and intimal nuclei in the aortic wall of the infected ones was compared with that of noninfected rats. The results were quantitated as the number of $\left[{ }^{3} \mathrm{H}\right] \mathrm{TdR}$ labeled nuclei in the adventitia, media, and intima using cross-sectional areas of the aorta.

Immunohistochemistry. Frozen and formaline-fixed 3-4- $\mu$ m-thick paraffine sections of aortic allografts were stained with immunoperoxidase (IP) technique at the time point of 1 mo using monoclonal antibodies to leukocyte common antigen (LCA, OX 1; Sera Lab, Sussex, $\mathrm{UK}$ ) and $\alpha$-smooth muscle actin (Bio-Makor, Rehovot, Israel). The sections were stained using the two-layer indirect IP technique (21). The sections were incubated with monoclonal antibodies, washed, and incubated consecutively with peroxidase-conjugated rabbit antimouse Ig and goat anti-rabbit Ig, followed by treatment with the substrate solution containing the chromogen 3-amino-9-ethylcarbazole. Hydrogen peroxidase was added to the 3-amino-9-ethylcarbazole solution immediately before use. The specimens were counterstained with hematoxylin-eosin and aquamounted.

Statistical methods. All data are expressed as mean \pm SEM, if not otherwise indicated. The Mann-Whitney $U$ test ( $Z$ corrected for ties) (29) was used to evaluate the significances of histological and autoradiographic changes between infected and noninfected allografts at certain time points. The linear regression analysis $(30,31)$ was applied to evaluate the significances of histological changes between infected and noninfected allografts within time intervals. Here, the statistical difference between regression coefficients (slopes) of linear plots have been calculated. Linear regression analysis made it possible to use large sample sizes compared to Mann-Whitney $U$ test. It was not applied to autoradiographs of these groups owing to the shapes of the curves and hence small sample sizes. $P$ values $<0.05$ were regarded as statistically significant.

\section{Results}

\section{$C M V$ infection in the transplant recipient}

Aortic allografts were transplanted from the DA to the WF strain (allogeneic), or for control from the DA to the DA strain (syngeneic). Both types of recipients were infected with $10^{5}$ PFU of RCMV on day 1 (early infection), but only allografts on day 60 (late infection). A group of allograft and syngeneic graft recipients was left noninfected and used as controls.

The biology of RCMV infection in nonimmunosuppressed rats has previously been described in detail by Bruggeman et al. (32). The infected rats did not show any symptoms of the disease. Biopsies from the salivary glands were usually negative at 7 and $14 \mathrm{~d}$, but showed positivity at 1 and 3 mo after RCMV inoculation as demonstrated by plaque assays (chronic infection ). In contrast, liver and spleen were usually positive only at 7 and $14 \mathrm{~d}$, and negative later on (acute systemic infection). At 6 mo all organs biopsies cultured for plaque assays were negative (latent infection).

Sporadic inflammatory cells in the adventitia of aortic allografts and native thoracic aorta were found to be RCMV antigen positive by the IP technique. In syngeneic grafts no RCMV antigen positive cells were found by IP. Mast cells, perivascular adipose tissue, leukocytes, or small vessels in the adventitia of the thoracic aorta in syngeneic rats were seldom positive. 


\section{Effect of virus infection on histological changes in the allograft}

The following grafts were examined: $(a)$ in the early infection group, allografts were removed at 7 and $14 \mathrm{~d}$, and at 1,3 , and 6 mo after transplantation, and (b) in the late infection group allografts were removed at 7 and $14 \mathrm{~d}$, and 1 and 4 mo after infection. Alterations observed in the adventitia, media, and intima of the graft, as quantitated by standard morphometric principles, are given below (28).

\section{INFECTION ON THE IST POSTTRANSPLANT DAY}

The adventitia. The adventitia of nontransplanted normal control aorta consisted of a few cells only $(0.5 \pm 0.5$ PSU, \pm SD), which were mainly fibroblasts. In noninfected allografts, as confirmed by staining with anti-LCA (21) there was infiltration of white inflammatory cells in the adventitia, with a peak at $11.5 \pm 1.2 \mathrm{PSU}$ at $1 \mathrm{mo}$, whereafter the inflammation declined. In infected allografts (Fig. $1 a$ ), the inflammatory episode occurred earlier with a peak at $11.6 \pm 1.5$ PSU already during the 1 st week ( $P=0.025$ at the 1 st and 2 nd week $)$. After $1 \mathrm{mo}$, the intensity of inflammation in infected allografts declined to the level of noninfected allografts. The thickness of the adventitia (Fig. $1 b$ ) relates to inflammation and edema, and showed approximately the same time profile as did the cell nuclear counts.

The media. The number of cell nuclei in the media of nontransplanted aortas was $3.1 \pm 1.0$ PSU $( \pm S D)$. In noninfected allografts the number of media nuclei remained within the normal values until $1 \mathrm{mo}$, and thereafter a rapid reduction of media nuclei occurred with a fall to $0.8 \pm 0.2 \mathrm{PSU}$ at $3 \mathrm{mo}$. The reduction in the number of cell nuclei was due to media necrosis. In infected allografts (Fig. $1 \mathrm{c}$ ), the medial necrosis developed in the same course as in noninfected allografts.

The medial thickness (Fig. $1 d$ ) in control aorta was $5.0 \pm 0.4$ PSU $( \pm \mathrm{SD})$. As a consequence of the loss of medial cell nuclei, there was a small decrease in the thickness of media, to $4.3 \pm 0.2$ and $3.7 \pm 0.2$ PSU at $3 \mathrm{mo}$ in noninfected and infected allografts, respectively.

The intima. The luminal surface of the aortic wall is normally lined by the endothelial cell monolayer, i.e., on the average $0.9 \pm 0.2$ PSU $( \pm S D)$ nuclei only. The number of intimal cell nuclei in noninfected allografts was $2.3 \pm 0.4$, and $2.5 \pm 0.3$ PSU at 1 and $3 \mathrm{mo}$, respectively, reaching $3.7 \pm 0.8$ PSU at 6 mo. In infected allografts (Fig. $1 e$ ), the number of cells increased rapidly up to $3.6 \pm 0.7$ PSU at $1 \mathrm{mo}$, but remained unchanged at $3 \mathrm{mo}(P<0.05$ at the 1 st and $3 \mathrm{rd}$ months $)$. At $6 \mathrm{mo}$ posttransplantation, there was a minor loss in the number of a. Adventitial nuclei

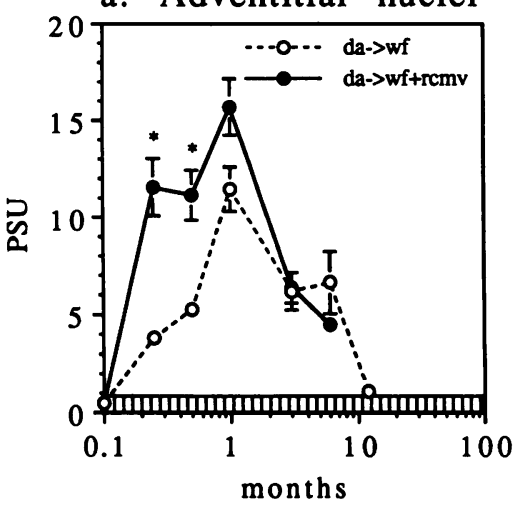

b. Adventitial thickness

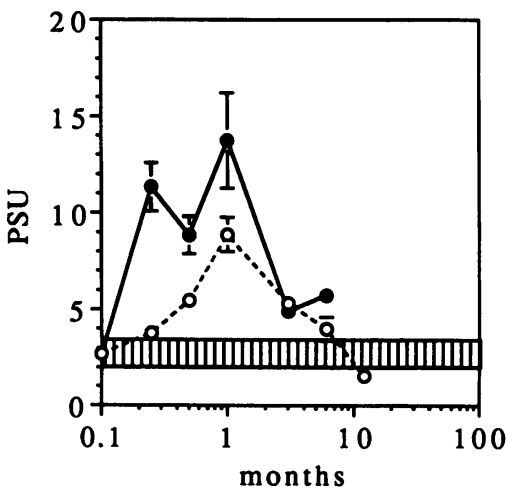

c. Media nuclei

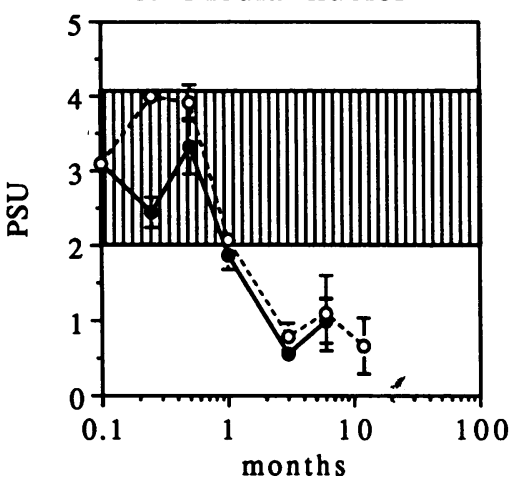

d. Media thickness

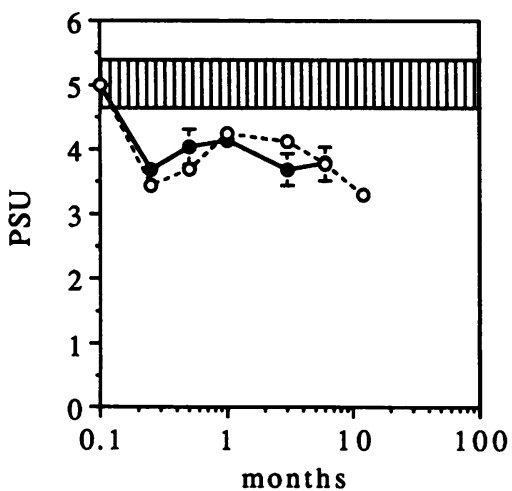

e. Intimal nuclei

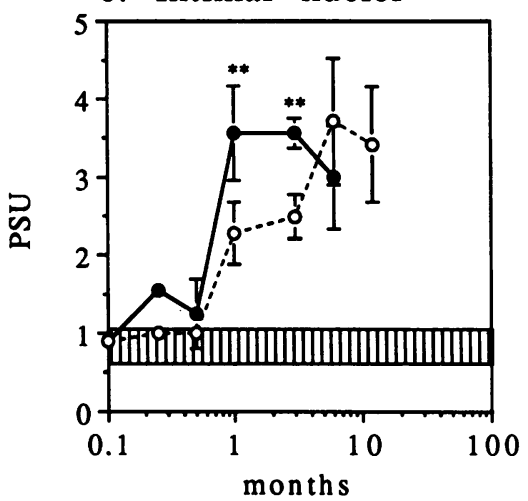

f. Intimal thickness

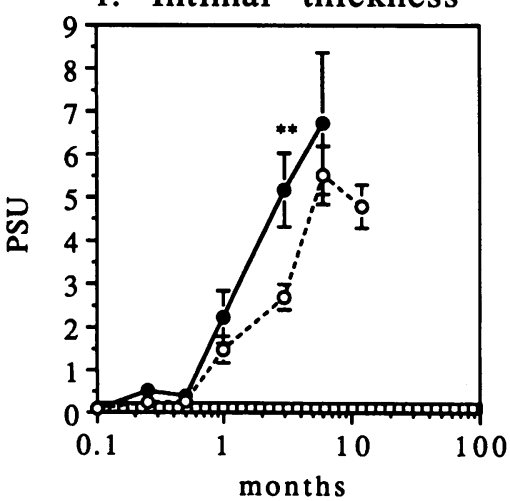

Figure 1. Effect of RCMV infection at the time of aortic transplantation (early infection) on the generation of accelerated allograft arteriosclerosis. The rats were infected i.p. with $10^{5} \mathrm{PFU}$ of RCMV on day 1 after transplantation, or left noninfected, and were killed at $7(n=5)$ and $14(n=5) \mathrm{d}$ and $1(n=4), 3(n=4)$, and $6(n=3)$ mo after transplantation. The corresponding numbers in control groups were 5, 3, 21, 11, 5 , and 5 . The responses are quantitated by PSU in the adventitia, media, and intima. Framed area = normal control aorta \pm SD. Mann-Whithey $U$ test was used to evaluate the significances between the experimental and the control groups, and are indicated as follows: ${ }^{*} P<0.05$ and ${ }^{* *} P$ $<0.025$. Note that the time is given in logarithmic scale, to emphasize the immediate posttransplant period. 
intimal cell nuclei in infected allografts compared with noninfected ones.

The intimal thickness of normal control aortas is nonexistent $(0.1 \pm 0.1 \mathrm{PSU}, \pm \mathrm{SD})$. In noninfected allografts, the thickness of the intima increased steadily reaching $2.7 \pm 0.3$ PSU at 3 mo, and a peak of 5.5 \pm 0.7 PSU at $6 \mathrm{mo}$. In infected allografts, intimal thickening occurred earlier (Fig. $1 f$ ), and the difference was significant even at 3 mo with $5.2 \pm 0.9$ PSU in the infected grafts compared with noninfected controls $(P<0.05)$. The enhanced increase in intimal thickness continued in infected allografts, and also thereafter, though in a lesser tempo, reaching $6.7 \pm 1.6$ PSU 6 mo after transplantation. There was cartilage and bone formation in two of five infected allografts at $6 \mathrm{mo}$; inasmuch as this distorts the morphological evaluation, these rats have been omitted from morphological measurements.

IP studies demonstrated that the rapid increase in the number of nuclei and thickness of intima at 1 mo in infected rats was largely due to the infiltration of LCA-positive inflammatory cells (histologically monocyte-macrophage lineage and lymphoid cells ) into the intima and edema, with minor proliferation of smooth muscle cells. In noninfected allografts, the intimal thickening was due to smooth muscle cell proliferation, as demonstrated also earlier by staining with $\alpha$-actin antibody (21) (Figs. 2 and 3). After $1 \mathrm{mo}$, the cytology of intimal proliferation in infected rats resembled that of the noninfected ones.

Regression analysis. To evaluate whether the histological changes in two groups were significantly different, an additional test, the linear regression analysis $(30,31)$, was applied to groups of noninfected and infected allografts. This analysis demonstrated (Table I) that the adventitial inflammation was indeed significantly stronger at day 7 after transplantation in the infected vs. noninfected allografts $(P=0.02)$, and that there was no difference in the intensity of media necrosis, whereas in the intima both the nuclear contents $(P=0.01$ up to $3 \mathrm{mo})$ and the intimal thickness ( $P=0.001$ up to $3 \mathrm{mo})$ were significantly more prominent in the infected grafts. This confirms the visual interpretation and the results of Mann-Whitney $U$ tests (indicated in Fig. 1) that CMV infection enhanced the early adventitial inflammation. It also enhanced intimal
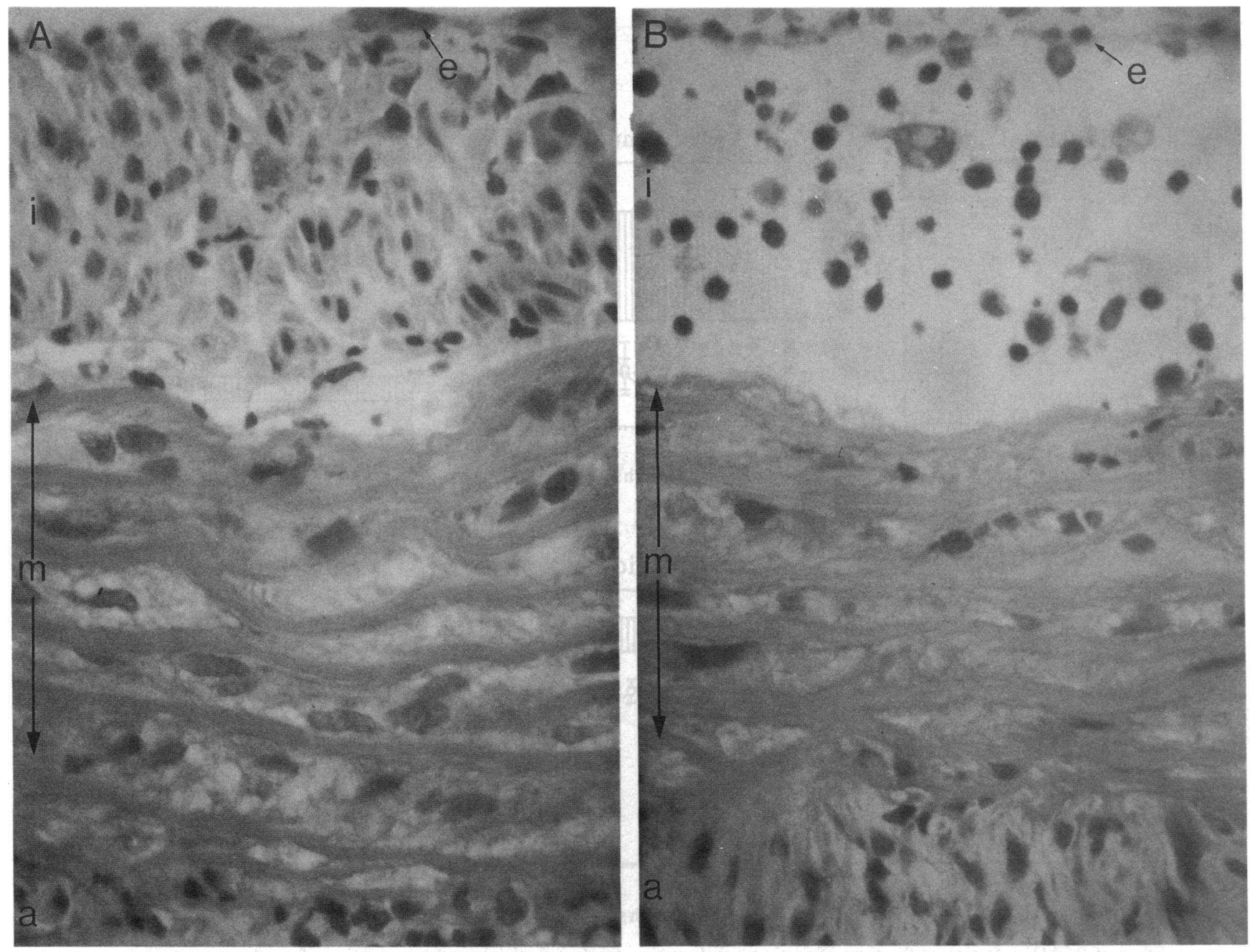

Figure 2. A microphotograph of the vascular wall of $(A)$ noninfected and $(B)$ infected allograft at 1 mo after transplantation. Note the infiltration of lymphoid cells and monocyte-macrophages into the intima and edema of the infected allograft, with minor proliferation of smooth muscle cells as demonstrated by LCA-antibody in IP staining (not shown). In noninfected allografts $(A)$, the intimal thickening is due to smooth muscle cells as also demonstrated by IP staining with $\alpha$-actin antibody (not shown). Abbreviations: $e$, endothelium; $i$, intima; $m$, media, separated by internal and external elastic laminae (vertical arrows); $a$, adventitia. Hematoxylin-eosin, $\times 400$. 


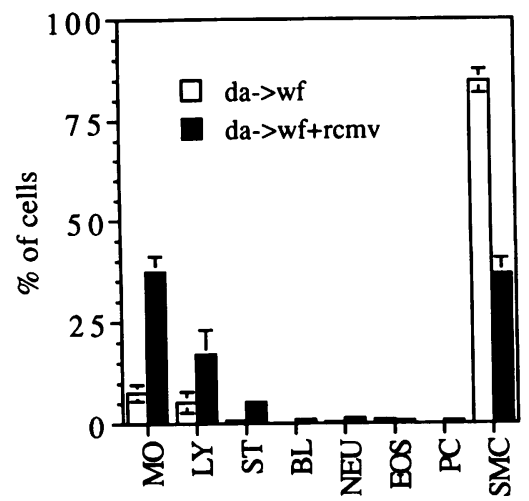

Figure 3. Semiquantitative analysis of intimal cells at 1 mo after transplantation on cytological criteria. The cell types in differential counts were abbreviated as follows: MO, monocyte-macrophage; LY, lymphocyte; ST, stimulated lymphocyte; $\mathrm{BL}$, blast cell; NEU, neutrophil; EOS, eosinophil; PC, plasma cell.

proliferation up to 3 mo after transplantation, whereafter the differences between the infected and noninfected groups leveled off.

INFECTION ON THE 60TH POSTTRANSPLANT DAY

The changes in the late infection group were much less impressive. The findings of this group are summarized in Fig. 4.

The adventitia. The number of adventitial nuclei in noninfected allografts was $11.4 \pm 1.2 \mathrm{PSU}$ at $2 \mathrm{mo}$. The infection with RCMV on the 60 th posttransplant day increased only slightly the number of inflammatory cells in the adventitia up to 12.6 \pm 7.2 PSU $(P=\mathrm{NS})$ in the 2 nd week after infection. Thereafter, the inflammatory response declined back to control allograft level (Fig. $4 a$ ). The thickness of the adventitia (Fig. $4 b$ ) followed approximately the same pace.

The media. There were $1.2 \pm 0.2$ PSU of media nuclei in noninfected allografts at $2 \mathrm{mo}$. In infected allografts, media necrosis was slightly enhanced, with a fall to $0.42 \pm 0.16$ PSU at the 1 st week after infection $(P=\mathrm{NS})$, and it remained below the level of noninfected allografts thereafter (Fig. $4 c$ ). The thickness of media followed the same time course (Fig. $4 d$ ).

The intima. At 2 mo there were $3.1 \pm 0.4$ PSU of nuclei in noninfected allografts. The number of nuclei increased up to
3.5 \pm 0.50 PSU $14 \mathrm{~d}$ after infection $(P=\mathrm{NS})$, but declined thereafter to the level of control allografts (Fig. $4 e$ ). The intimal thickness of noninfected allografts was $2.9 \pm 0.2$ PSU at 2 mo. There was a transient increase up to $4.4 \pm 0.3 \mathrm{PSU}$ in infected allografts $(P=\mathrm{NS})$, whereas no difference was found after this time point (Fig. $4 f$ ).

\section{Effect of virus infection on histological changes in the syngeneic grafts}

The syngeneic grafts were examined at 7 and $14 \mathrm{~d}$, and 1 and 3 mo after transplantation. Changes in the three layers of the vessel wall were quantitated; normal values of control nontransplanted aorta are given above. The findings of the syngeneic grafts are summarized in Fig. 5.

The adventitia. The number of adventitial nuclei in noninfected syngeneic grafts varied from $3.5 \pm 0.5$ to $2.3 \pm 0.5$ PSU at $7 \mathrm{~d}$ and $3 \mathrm{mo}$, respectively. In infected syngeneic grafts there was a slight inflammatory episode at $7 \mathrm{~d}$, but thereafter the number of adventitial nuclei was similar to noninfected rats (Fig. $5 a$ ).

The media. The number of media nuclei in noninfected and infected syngeneic grafts remained within the normal values of nontransplanted aorta (3.1 $\pm 1.0 \mathrm{PSU}, \pm \mathrm{SD})$ during the whole observation period (Fig. $5 c$ ).

The intima. In noninfected syngeneic grafts, no intimal proliferation was observed. In infected syngeneic grafts, however, a slight intimal nuclear response was recorded at $1 \mathrm{mo}$, but the difference was not of statistical significance (Fig. $5 e$ ). In noninfected syngeneic grafts no intimal thickening was observed. In infected rats, there was only a minor increase in intimal thickness at 1 mo (Fig. $5 f$ ). Taken together, viral infection on syngeneic transplants had no impact.

Effect of virus infection on the histological changes in the nontransplanted descending thoracic aorta

No morphological alterations were observed in the native thoracal aorta of the infected rats.

Table I. Linear Regression Analysis for Evaluation of Tendencies of Arteriosclerotic Alterations in the Vascular Wall of Noninfected and Infected Allografts within Different Time Intervals

\begin{tabular}{|c|c|c|c|c|c|c|}
\hline \multirow[b]{2}{*}{ Parameter } & \multirow[b]{2}{*}{ Time interval } & \multicolumn{2}{|c|}{$\mathrm{DA} \rightarrow \mathrm{WF}$} & \multicolumn{2}{|c|}{$\mathrm{DA} \rightarrow \mathrm{WF}+\mathrm{RCMV}$} & \multirow[b]{2}{*}{$P$ value } \\
\hline & & No. & Slope & No. & Slope & \\
\hline & $m o$ & & & & & \\
\hline \multirow[t]{3}{*}{ Adventitial nuclei } & $0-0.25$ & 10 & 2.8 & 10 & 35.2 & 0.02 \\
\hline & $0-0.5$ & 13 & 4.8 & 15 & 16.8 & NS \\
\hline & $0-1$ & 34 & 9.5 & 19 & 11.5 & NS \\
\hline Media nuclei & $0.5-6$ & 40 & -0.4 & 16 & -0.4 & NS \\
\hline \multirow[t]{3}{*}{ Intimal nuclei } & $0-1$ & 34 & 1.6 & 19 & 2.5 & 0.02 \\
\hline & $0-3$ & 45 & 0.5 & 23 & 0.9 & 0.01 \\
\hline & $0-6$ & 50 & 0.3 & 26 & 0.4 & NS \\
\hline \multirow[t]{3}{*}{ Intimal thickness } & $0-1$ & 34 & 1.5 & 19 & 2.0 & 0.01 \\
\hline & $0-3$ & 45 & 0.8 & 23 & 1.7 & 0.001 \\
\hline & $0-6$ & 50 & 0.7 & 26 & 1.2 & NS \\
\hline
\end{tabular}

Linear regression analysis yielded the slope of the curve (regression coefficient) and the position of the slope was used to test the significances. 
a. Adventitial nuclei
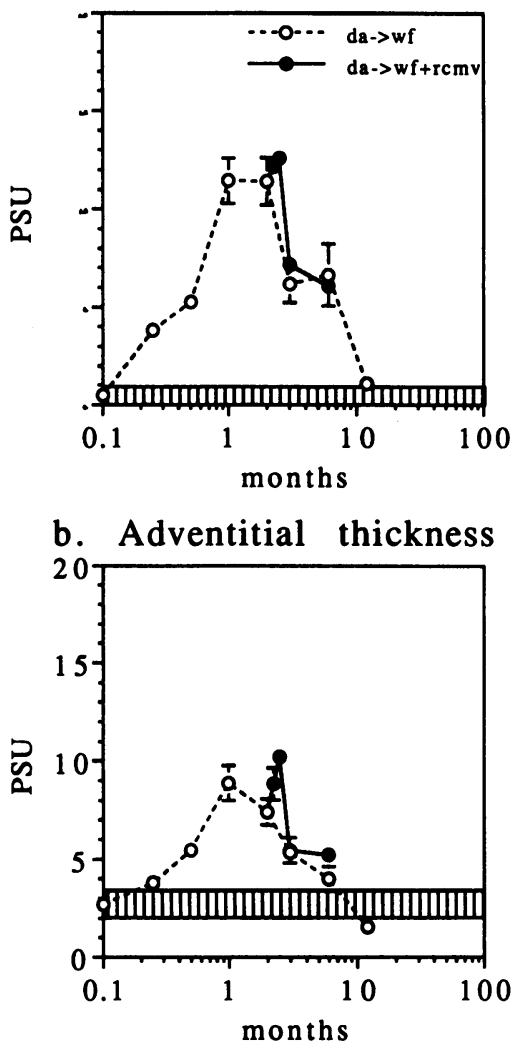

c. Media nuclei

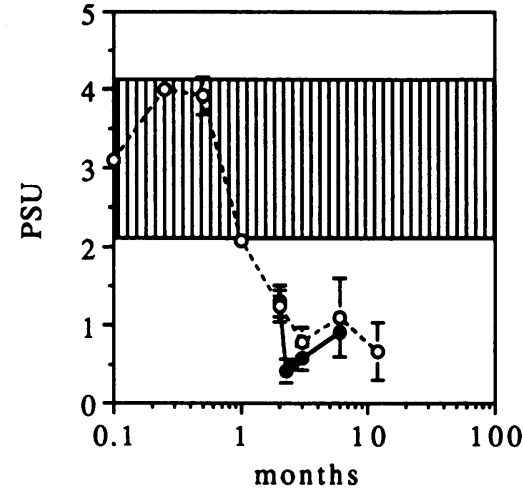

d. Media thickness

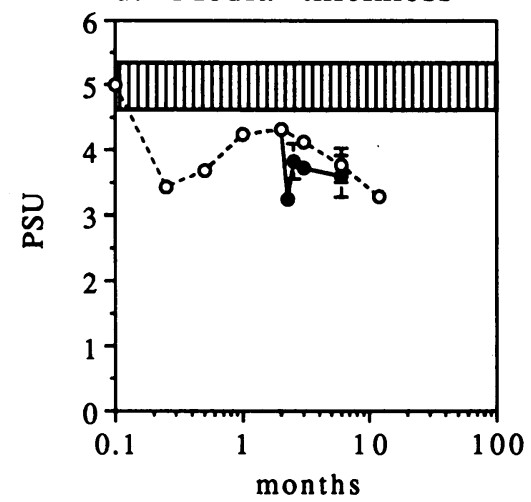

e. Intimal nuclei

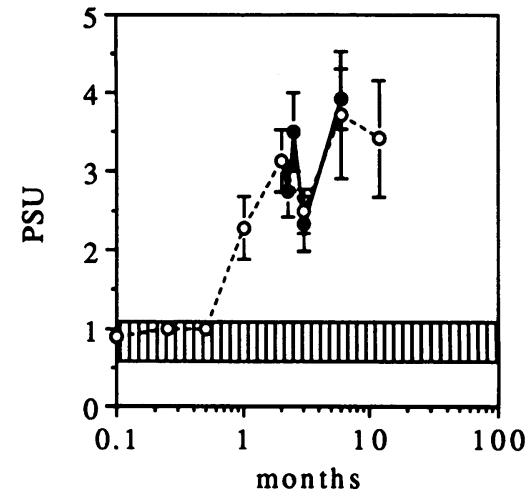

f. Intimal thickness

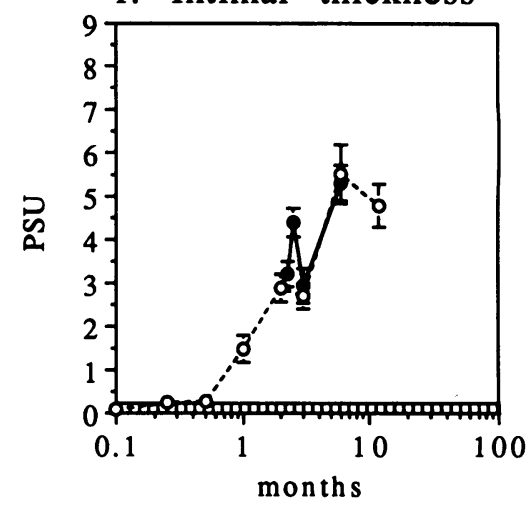

Figure 4. Effect of RCMV infection on the generation of allograft arteriosclerosis, when the virus was inoculated i.p. $60 \mathrm{~d}$ after transplantation. The rats were killed $7(n=3)$ and $14(n=3) \mathrm{d}$, and $1(n=3)$ and $4(n=3)$ mo after RCMV infection. The corresponding numbers of the control group were 5, 3,21, 22, 11, 5, and 3. The responses are quantitated by PSU in the adventitia, media, and intima. For explanation of symbols, see the text of Fig. 1.

\section{Impact of virus infection on cell proliferation in the vascular wall}

All rats received $\left[{ }^{3} \mathrm{H}\right] \mathrm{TdR}$ before sacrifice. The autoradiograms were performed from paraffin sections, and the proliferation was quantitated as the number of $\left[{ }^{3} \mathrm{H}\right] \mathrm{TdR}$-labeled nuclei per cross section.

Adventitial cell proliferation. In noninfected allografts there was an increase in the number of $\left[{ }^{3} \mathrm{H}\right] \mathrm{TdR}$-incorporating cells in the adventitia, from 0 to $88 \pm 3$ cells at the 1 st week, and to $225 \pm 25$ cells at $1 \mathrm{mo}$. The high level of white cell proliferation in the adventitia lasted for $3 \mathrm{mo}$, and declined thereafter. In infected allografts there was a more rapid and intensive peak of white cell proliferation at the 1st posttransplant week $227 \pm 21$ $(P<0.05)$. Thereafter the proliferative response declined gradually, returning to the level of noninfected allografts, and declining even below that after $1 \mathrm{mo}(P<0.025$ at 1 and $3 \mathrm{mo}, P$ $<0.05$ at $6 \mathrm{mo}$ ) (Fig. $6 a$ ).

Media cell proliferation. There was also an increase in the number of $\left[{ }^{3} \mathrm{H}\right] \mathrm{TdR}$ incorporating cells in the media of noninfected allografts lasting for 1-3 mo. In infected allografts, the increase was more prominent at the 1 st and 2 nd weeks $(P<0.05$ at $1 \mathrm{wk}, P<0.025$ at $2 \mathrm{wk})$, but declined thereafter (Fig. $6 b$ ).

Intimal cell proliferation. Proliferating cells in the intima of noninfected allografts were first observed after 2 wk. Thereafter, the proliferative response in the intima continued at least for 6 mo, i.e., to the end of the observation time. In infected allografts, the intimal cell proliferation was more intensive throughout the observation time $(P<0.025$ at $1 \mathrm{wk}$; thereafter NS) (Fig. $6 c$ ).

Cell proliferation in late infection group and syngeneic grafts. Cell proliferation in the late infection group and syngeneic grafts did not differ from that of noninfected transplants, neither did the histological response to viral infection (Figs. 7 and 8).

\section{Discussion}

Strong clinical evidence has been recently provided that CMV infection enhances cardiac allograft arteriosclerosis in human heart allografts (12-14). In addition, an association of CMV infection in cardiac transplant recipients with more frequent allograft rejections and death is suggested in one of these studies (12). Furthermore, a link between viral infections, especially herpesviruses, and classical atherosclerosis is substantiated by the observations of Fabricant et al. (16), who showed that Marek's disease herpesvirus caused atherosclerotic lesions in chicken which closely resembled those observed in classical atherosclerosis in human arteries.

In this report we provide, for the first time, experimental evidence that $\mathrm{CMV}$ infection accelerates allograft arteriosclerosis. RCMV infection at the time of transplantation has two important effects on the generation of accelerated arteriosclerosis in aortic allografts. First, the infection is associated with an 
a. Adventitial nuclei

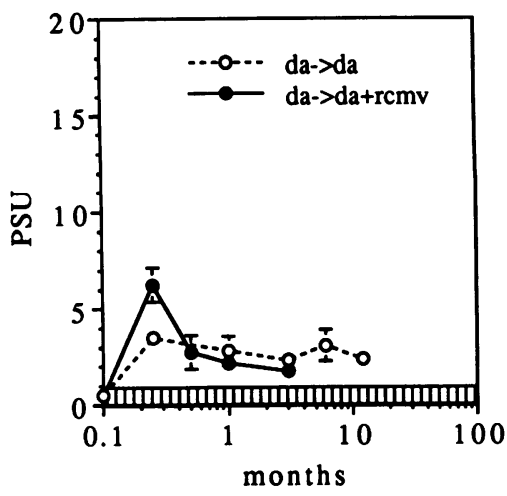

b. Adventitial thickness

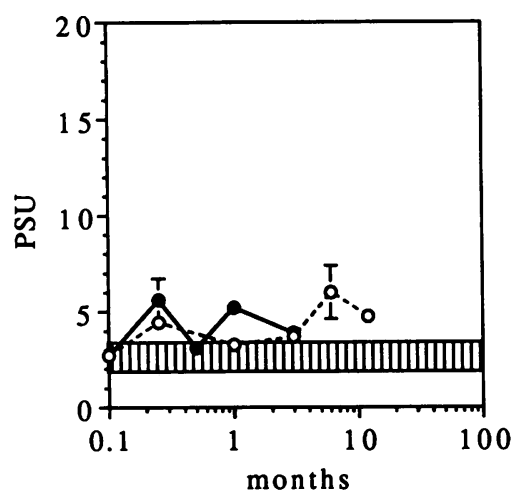

c. Media nuclei

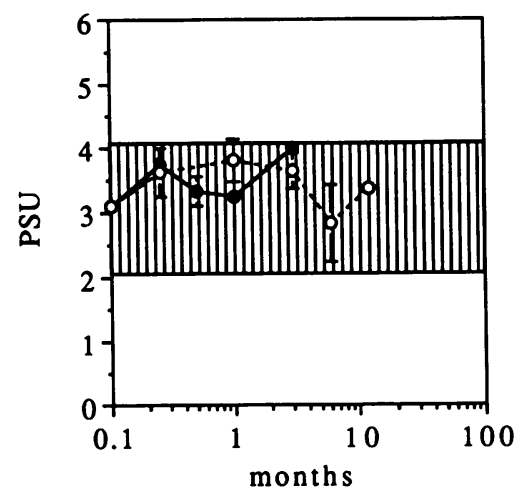

d. Media thickness

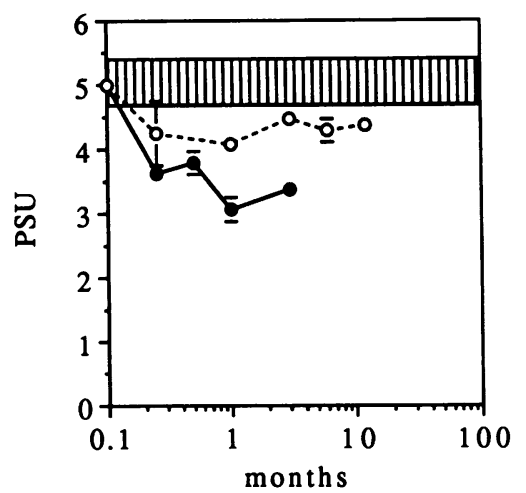

e. Intimal nuclei

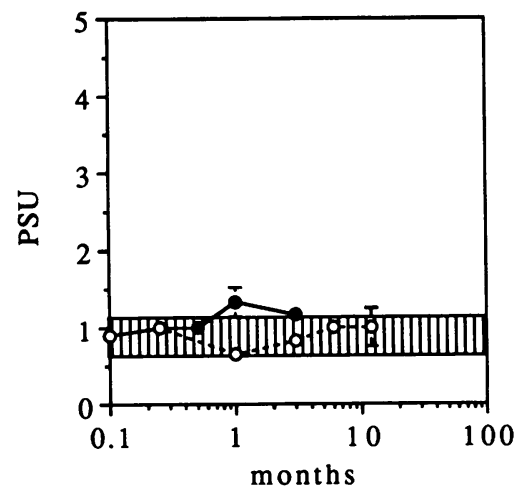

f. Intimal thickness

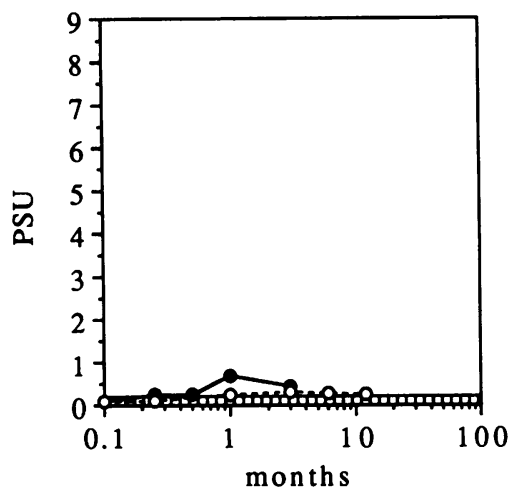

Figure 5. Effect of RCMV infection at the time of aortic transplantation on syngeneic grafts. The rats were infected i.p. with $10^{5} \mathrm{PFU}$ of RCMV on day 1 after transplantation, or left noninfected, and killed at $7(n=3)$ and $14(n=3) \mathrm{d}$ and $1(n=3)$ and $3(n=3)$ mo after transplantation. The corresponding numbers of the control group were $3,0,8$, and 10 . The responses are quantitated by PSU in the adventitia, media, and intima. For explanation of symbols, see the text of Fig. 1.

early prominent inflammatory episode and proliferation of inflammatory cells in the allograft adventitia. Second, the viral infection doubled the proliferation of smooth muscle cells and the arteriosclerotic alterations in the intima. We consider the accelerated intimal changes, which have been observed only in virus-infected allografts, to be due to the early prominent inflammation in the arterial wall. The specificity of the early replicating lymphoid cell populations in the allograft infiltrate have not yet been defined.

If the timepoint of infection is postponed by $2 \mathrm{mo}$, the impact of RCMV infection on the allograft histological changes is small. This is also the case if syngeneic grafts are infected with RCMV at the time of transplantation. Thus, an acute alloimmune response must be associated with virus infection, to induce accelerated allograft arteriosclerosis. Our studies in CMV infected human heart allografts have demonstrated that a similar inflammatory response, subendothelial lymphocytosis, in vessel walls with alterations of small intramyocardial arterioles leading to narrowing of the vascular lumen of the graft were related to CMV infection (33).

What would then be the plausible mechanisms whereby CMV infection enhances allograft arteriosclerosis? CMV is capable of infecting components of the vascular wall, in particular, endothelial cells (34-36) and smooth muscle cells (37). Like all other herpesviruses, CMV is able to turn into the latent state after acute infection. In latent CMV infection of smooth muscle cells (19), detected by tracing viral genes and antigens
$(17,18)$, the virus may transform the smooth muscle cells by incorporating into the cell genome, and induce local proliferation and changes in cellular metabolism of these cells, e.g., production of different growth factors, without destroying them $(38-40)$. These possibilities will be considered in an separate communication.

Early CMV infection significantly enhanced the early adventitial inflammatory episode. During acute CMV infection, enhancement of several molecular inflammatory cascades may take place. Studies in the aortic allograft model (41) demonstrate that, during the induction of allograft arteriosclerosis in the absence of CMV virus, several cytokines (including IL-1 and $\gamma$-interferon) and growth factors (including epidermal growth factor, insulinlike growth factor- 1 and platelet-derived growth factor) are prominently expressed in the vascular wall both on the peptide and the mRNA level, although the levels of eicosanoids are not altered. In addition, this latent infection may prolong the inflammatory responses so that the cell components of the vascular wall may be under continuous influence of different cytokines.

Studies with mouse CMV have suggested that natural killer cells have an important role in limiting acute CMV infection (42). It was further noticed that two kinds of cytotoxic T cells were produced against immediate and late antigens produced during acute mouse CMV infection $(43,44)$. In addition, $\mathrm{CMV}$, like other herpesviruses, induces the expression of IgG Fc receptors on the virus-infected cells (45), and thus allows 


\section{a.Adventitial nuclei}

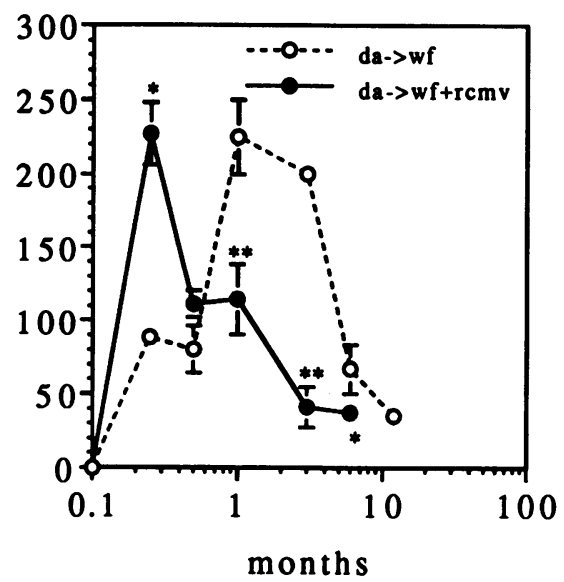

\section{b.Media nuclei}

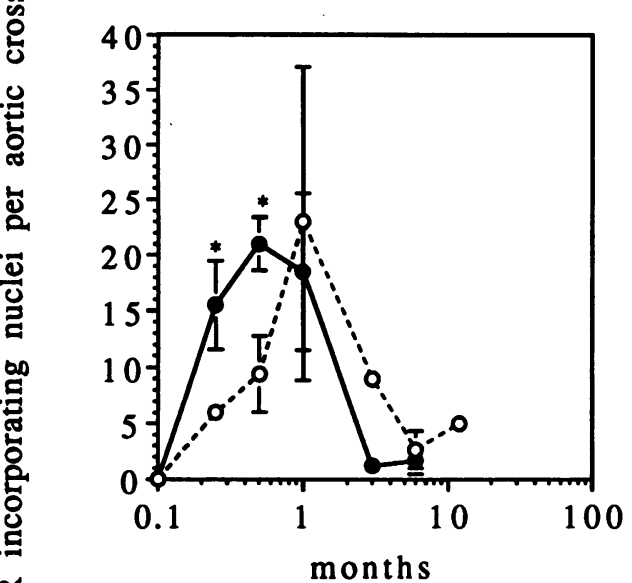

雚

\section{c. Intimal nuclei}

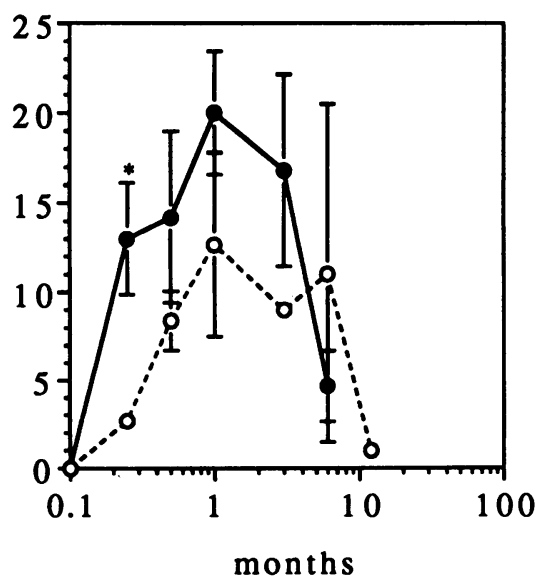

Figure 6. Autoradiograms for proliferating cells in the three layers of allograft vascular wall, when the virus was inoculated i.p. at the time of transplantation. All rats received $\left[{ }^{3} \mathrm{H}\right] \mathrm{TdR}$ i.v. $3 \mathrm{~h}$ before sacrifice. The autoradiograms were quantitated as the number of thymidine incorporating nuclei in cross sections of different layers of aorta. There was no proliferation in nontransplanted aortas. Noninfected DA-WF allografts $\pm \operatorname{SEM}(n=3,5,4,3,3$, and 3); RCMV-infected allografts $\pm \operatorname{SEM}(n=5,4,4,5$, and 3$)$. Mann-Whithey $U$ test was used to test significances between the experimental and the control groups, and are indicated as follows: ${ }^{*} P<0.05$ and ${ }^{* *} P<0.025$. Note that the time is given in logarithmic scale, to emphasize the immediate posttransplant period.

\section{A. adventitial nuclei}

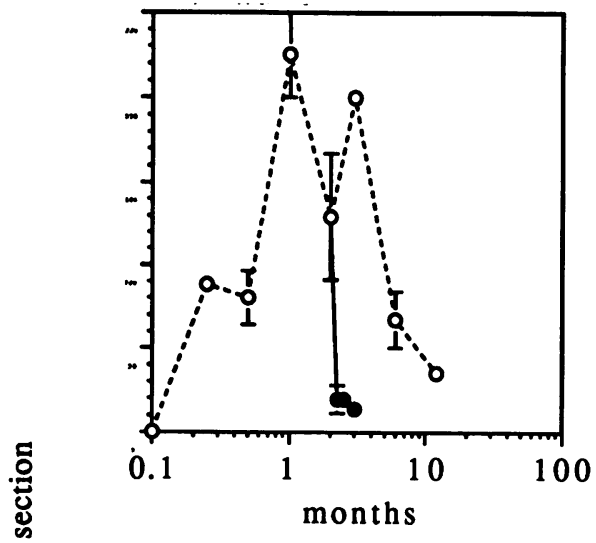

b. Media nuclei

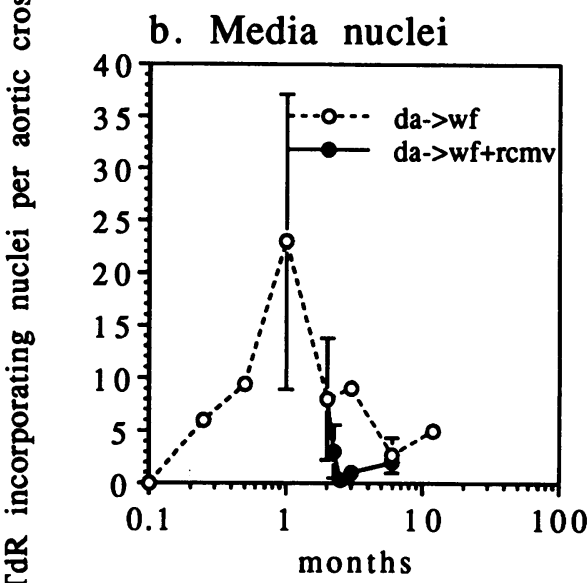

c. Intimal nuclei

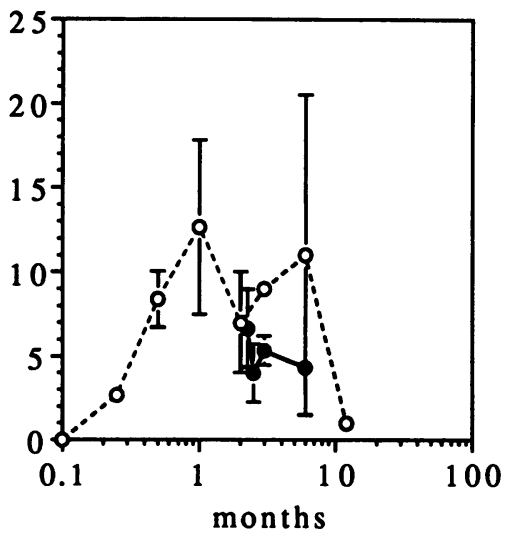

Figure 7. Autoradiograms for proliferating cells in the three layers of allograft vascular wall, when the virus was inoculated i.p. 2 mo after transplantation. For explanation of symbols, see the legend to Fig. 6.

interaction with granulocytes (46), leading to cell damage through enzyme release and oxygen radicals. Furthermore, human CMV infection up-regulates IL- $1 \beta$ gene expression leading to increased production of IL-1 by monocyte-macrophage cell lineage, and to enhancement of inflammatory responses $(47)$.

The immediate early gene of human CMV is able to code for a protein that has sequence homology and immunologic cross-reactivity with HLA-DR $\beta$ chain, thus possibly enhancing alloimmune responses to donor antigens (48). CMV also 


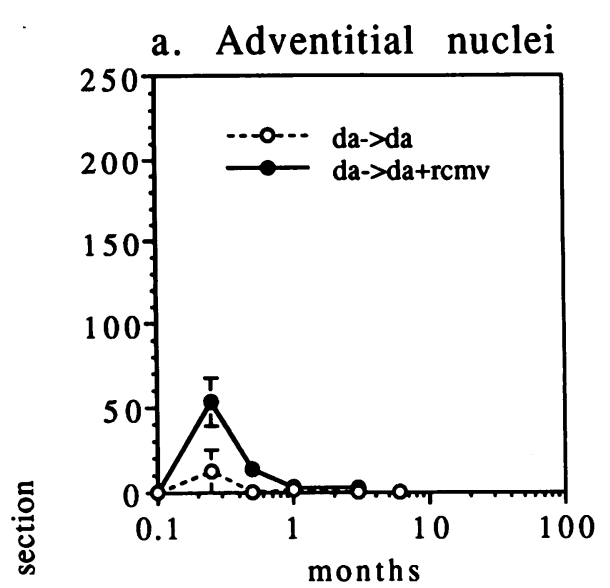

b. Media nuclei

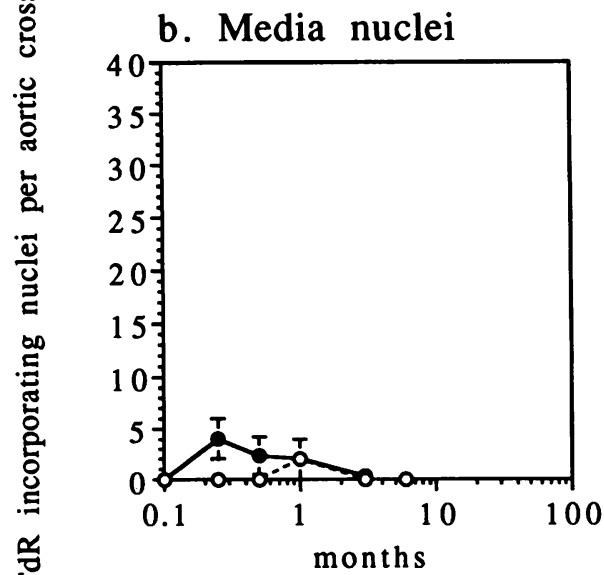

c. Intimal nuclei

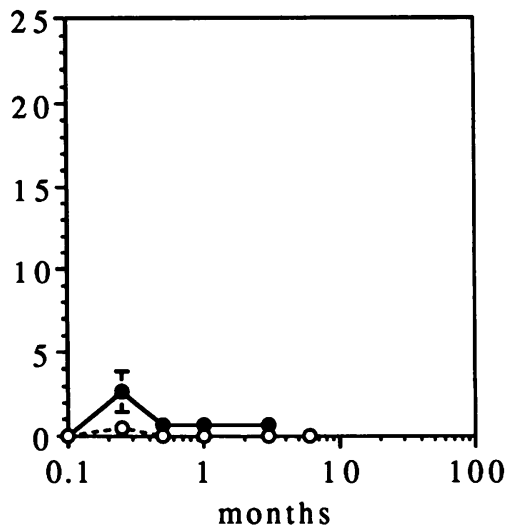

Figure 8. Autoradiograms for proliferating cells in the three layers of vascular wall in syngeneic grafts, when RCMV was inoculated on day 1 after transplantation. The infected rats were killed $7(n=3)$ and $14(n=3) \mathrm{d}$, and $1(n=3)$ and $3(n=3)$ mo after transplantation. The corresponding number for noninfected syngeneic rats were 2, 0, 3, and 3. For explanation of symbols, see the legend to Fig. 6.

encodes a glycoprotein homologous with the heavy chain of MHC class-I antigens that has the ability to bind the light chain of MHC class-I molecule, i.e., to the $\beta_{2}$-microglobulin (49). These inflammatory and immunologic phenomena in response to injury (50) induced by viral infection may lead to endothelial cell monolayer damage, and to the exposure of smooth muscle cells to cytokines and growth factors and to the virus itself. These possibilities will be answered in future studies.
Proliferating response of smooth muscle cells in RCMV infected and noninfected allografts seems to be a self-limiting process. As clearly seen in autoradiograms, in noninfected allografts the proliferation of smooth muscle cells in the intima declines close to zero level at 10-12 mo after transplantation, whereas in RCMV-infected allografts, where the response takes place earlier and is more intense, the proliferation stops already at 5-6 mo after transplantation. After this time point, the histological lesion also stops progressing, but plateaus off. Hayflick (51) 20 yr ago described how human diploid cell strains have a limited in vitro lifetime. Ross et al. (52) demonstrated in their experiments that smooth muscle cells derived from advanced atherosclerotic lesions of the superficial femoral artery have a limited capacity for cell division in vitro as compared to smooth muscle cells derived from nonaffected areas of the underlying media.

To conclude, our studies demonstrate that RCMV infection enhances allograft arteriosclerosis in rat aortic allografts, with the prerequisite that an acute alloimmune response and acute virus infection coincide. When applied to the clinical situation, the results emphasize that CMV-negative recipient receiving a CMV-positive graft is in particularly great danger of developing enhanced graft arteriosclerosis. Our experiments have not yet provided any conclusive answer as to which are the molecular mechanisms of viral infection in the vascular wall. Tracking of viral antigens and viral genome in the graft and descending thoracic aorta of the recipient is in progress. This experimental animal model will make it possible, for the first time, to investigate the pathophysiology of viral infection in the vascular wall of transplant recipients, and enables us to develop logistics for prophylaxis and treatment of CMV-enhanced allograft arteriosclerosis with antiviral regimens.

\section{Acknowledgments}

We are grateful to Ms. E. Wasenius, R.N., Lab. and T. Lahtinen, R.N., Lab. for excellent technical assistance.

This work was supported by grants from The Academy of Finland, The Sigrid Juselius Foundation, and University of Helsinki, Finland.

\section{References}

1. Kaye, M. P. 1992. The registry of The International Society for Heart and Lung Transplantation: Ninth Official Report 1992. J. Heart Lung Transplant. 11:599-606.

2. Barnart, G. R., E. A. Pascoe, A. C. Mills, S. Szentpetery, D. M. Eich, T Mohanakumar, A. Hastillo, J. A. Thompson, M. L. Hess, and R. R. Lower. 1989. Accelerated coronary arteriosclerosis in cardiac transplant recipients. Transplant. Rev. 1:31-46.

3. Billingham, M. E. 1992. Histopathology of graft coronary disease. J. Heart Lung Transplant. 11:S38-S44.

4. Gao, S. Z., E. L. Alderman, J. S. Schroeder, J. F. Silverman, and S. A. Hunt. 1988. Accelerated coronary vascular disease in the heart transplant patient: coronary arteriographic findings. J. Am. Coll. Cardiol. 12:334-340.

5. Olivari, M. T., D. C. Homans, R. F. Wilson, S. H. Kubo, and W. S. Ring. 1989. Coronary artery disease in cardiac transplant patients receiving triple-drug immunosuppressive therapy. Circulation. 80:S. III:111-115.

6. Johnson, D. E., E. L. Alderman, J. S. Schroeder, S. Z. Gao, S. Hunt, W. M. Decampli, E. Stinson, and M. Billingham. 1991. Transplant coronary artery disease: histopathologic correlations with angiographic morphology. J. Am. Coll. Cardiol. 17:449-457.

7. Taylor, D. O., H. M. Ibrahim, D. R. Tolman, and M. L. Hess. 1991 Accelerated coronary atherosclerosis in cardiac transplantation. Transplant. Rev. 5:165-174.

8. Hosenpud, J. D., G. D. Shipley, and C. R. Wagner. 1992. Cardiac allograft vasculopathy: current concepts, recent developments, and future directions. $J$. Heart Lung Transplant. 11:9-23.

9. Stovin, P. G. I., L. Sharples, J. A. Hutter, J. Wallwork, and T. A. H. English. 
1991. Some prognostic factors for the development of transplant-related coronary artery disease in human cardiac allografts. J. Heart Lung Transplant. 10:3844.

10. Sharples, L. D., N. Caine, P. Mullins, J. P. Scott, E. Solis, T. A. H. English, S. R. Large, P. M. Schofield, and J. Wallwork. 1991. Risk factor analysis for the major hazards following heart transplantation-rejection, infection, and coronary occlusive disease. Transplantation. 51:244-252.

11. Dummer, J. S., L. T. White, M. Ho, B. P. Griffith, R. L. Hardesty, and H. T. Bahnson. 1985. Morbidity of cytomegalovirus infection in recipients of heart or heart-lung transplants who received cyclosporine. J. Infect. Dis. 152:1182-1191.

12. Grattan, M. T., C. E. Moreno-Cabral, V. A. Starnes, P. E. Oyer, E. B. Stinson, and N. E. Shumway. 1989. Cytomegalovirus infection is associated with cardiac allograft rejection and atherosclerosis. JAMA (J. Am. Med. Assoc.). 261:3561-3566.

13. Loebe, M., S. Schüler, Z. Ortwin, H. Warnecke, E. Fleck, and R. Hetzer. 1990. Role of cytomegalovirus infection in the development of coronary artery disease in the transplanted heart. J. Heart Transplant. 9:707-711.

14. McDonald, K., T. S. Rector, E. A. Braunlin, S. H. Kubo, and M. T. Olivari. 1989. Association of coronary artery disease in cardiac transplant recipients with cytomegalovirus infection. Am. J. Cardiol. 64:359-362.

15. Hruban, R. H., T.-C. Wu, W. E. Beschorner, D. E. Cameron, R. F. Ambinder, W. A. Baumgartner, G. M. Hutchins, and B. A. Reitz. 1990. Cytomegalovirus nucleic acids in allografted hearts. Hum. Pathol. 21:981-983.

16. Fabricant, C. G., J. Fabricant, M. M. Litrenta, and C. R. Mimick. 1978. Virus-induced atherosclerosis. J. Exp. Med. 148:335-340.

17. Hendrix, M. G. R., M. M. M. Salimans, C. P. A. van Boven, and C. A. Bruggeman. 1990. High prevalence of latently present cytomegalovirus in arterial walls of patients suffering from grade III atherosclerosis. Am. J. Pathol. 136:2328.

18. Hendrix, M. G. R., P. H. J. Dormans, P. Kitslaar, F. Bosman, and C. A Bruggeman. 1989. The presence of cytomegalovirus nucleic acids in arterial walls of atherosclerotic and non-atherosclerotics patients. Am. J. Pathol. 134:11511157.

19. Melnick, J. L., G. R. Dreesman, C. H. McCollum, B. L. Petrie, J. Burek, and M. E. DeBakey. 1983. Cytomegalovirus antigen within human arterial smooth muscle cells. Lancet. II:644-647.

20. Span, A. H. M., G. Grauls, F. Bosman, C. P. A. van Boven, and C. A. Bruggeman. 1992. Cytomegalovirus infection induces vascular injury in the rat. Atherosclerosis. 93:41-52.

21. Mennander, A., S. Tiisala, J. Halttunen, S. Yilmaz, T. Paavonen, and P. Häyry. 1991. Chronic rejection in rat aortic allografts: an experimental model for transplant arteriosclerosis. Arterioscler. Thromb. 11:671-680.

22. Bruggeman, C. A., H. Meijer, P. H. J. Dormans, W. M. H. Debie G. E. L. M. Grauls, and C. P. A. van Boven. 1982. Isolation of a cytomegaloviruslike agent from wild rats. Arch. Virol. 73:231-241.

23. Bruggeman, C. A., W. M. H. Debie, G. Grauls, G. Majoor, and C. P. A. van Boven. 1983. Infection of laboratory rats with a new cytomegalo-like virus. Arch. Virol. 76:188-199.

24. Arvin, A. M. 1985. Cytomegaloviruses. In Laboratory Diagnosis of Viral Infections. E. H. Lennette, editor. Marcel Dekker, Inc., New York. 506 pp.

25. Wentworth, B., and L. French. 1970. Plaque assay of CMV strains of human origin. Proc. Soc. Exp. Biol. Med. 135:253-258.

26. Stals, F. S., F. Bosman, C. P. A. van Boven, and C. A. Bruggeman. 1990 An animal model for therapeutic intervention studies of CMV infection in the immunocompromised host. Arch. Virol. 114:91-107.

27. Bruning, J. H., W. H. M. Debie, P. H. J. Dormans, H. Meyer, and C. A Bruggeman. 1987. The development and characterization of monoclonal antibodies against rat cytomegalovirus induced antigens. Arch. Virol. 94:55-70.

28. Aherne, W. A., and M. S. Dunnill. 1980. Morphometry. Edward Arnold, London. $170 \mathrm{pp}$.

29. Pipkin, F. B. 1984. Medical Statistics Made Easy. Churchill Livingstone, Edinburgh. $138 \mathrm{pp}$.

30. Armitage, P., and G. Berry. 1986. Further analysis of straight-line data. In Statistical Methods in Medical Research. Blackwell Scientific Publications, Oxford, UK. 559 pp. 2nd edition.
31. Montgomery, D., and E. Peck. 1982. Introduction to Linear Regression Analysis. John Wiley \& Sons, Inc., New York. 504 pp.

32. Bruggeman, C. A., H. Meijer, F. Bosman, and C. P. A. van Boven. 1985 Biology of rat cytomegalovirus infection. Intervirology. 24:1-9.

33. Koskinen, P. K., L. A. Krogerus, M. S. Nieminen, S. P. Mattila, P. J. Häyry, and I. T. Lautenschlager. 1993. Quantitation of cytomegalovirus infection associated histological findings in endomyocardial biopsies of heart allografts. $J$. Heart Lung Transplant. In press.

34. Smiley, M. L., E.-C. Mar, and E.-S. Huang. 1988. Cytomegalovirus infection and viral-induced transformation of human endothelial cells. J. Med. Virol. 25:213-226.

35. Friedman, H. M., E. J. Macarak, R. R. MacGregor, J. Wolfe, and N. A. Kefalides. 1981. Virus infection of endothelial cells. J. Infect. Dis. 143:266-273. 36. Span, A. H. M., P. M. Frederik, G. Grauls, C. P. A. van Boven, and C. A. Bruggeman. 1993. CMV induced vascular injury: an electronmicroscopic study in the rat. Atherosclerosis. In press.

37. Tumilowicz, J. J., M. E. Gawlik, P. P. Bowell, and J. J. Trentin. 1985. Replication of cytomegalovirus in human arterial smooth muscle cells. J. Virol. 56:839-845.

38. Hajjar, D. P. 1991. Viral pathogenesis of atherosclerosis: impact of molecular mimicry and viral genes. Am. J. Pathol. 139:1195-1211.

39. Melnick, J. L., E. Adam, and M. E. DeBakey. 1990. Possible role of cytomegalovirus in atherogenesis. JAMA (J. Am. Med. Assoc.). 263:2204-2207.

40. Benditt, E. P., T. Barrett, and J. K. Dougall. 1983. Viruses in the etiology of atherosclerosis. Proc. Natl. Acad. Sci. USA. 80:6386-6389.

41. Häyry, P., A. Mennander, A. Räisänen-Sokolowski, J. Ustinov, K. Lemström, P. Aho, S. Yilmaz, I. Lautenschlager, and T. Paavonen. 1993. Pathophysiology of vascular wall changes in chronic allograft rejection. Transplant. Rev. 7:1-20.

42. Shellam, G. R., J. E. Allen, J. M. Papadimitroiou, and G. J. Bancroft. 1981. Increased susceptibility to cytomegalovirus infection in beige mutant mice. Proc. Natl. Acad. Sci. USA. 78:5104-5108.

43. Reddehase, M. J., G. M. Keil, and U. H. Koszinowski. 1984. The cytolytic T lymphocyte response to the murine cytomegalovirus. I. Distinct maturation stages of cytolytic $\mathrm{T}$ lymphocytes constitute the cellular immune response during acute infection of mice with the murine cytomegalovirus. J. Immunol. 132:482489.

44. Reddehase, M. J., G. M. Keil, and Koszinowski. 1984. The cytolytic T lymphocyte response to the murine cytomegalovirus. II. Detection of virus replication stage-specific antigen by separate populations of in vivo active cytolytic $T$ lymphocyte precursors. Eur. J. Immunol. 14:56-61.

45. Keller, R. R., J. N. Peitchel, J. N. Goldman, and M. Goldman. 1976. An IgG-Fc receptor induced in cytomegalovirus-infected human fibroblasts. $J$. Immunol. 116:772-777.

46. MacGregor, R. R., H. M. Friedman, E. J. Macarak, and N. A. Kefalides. 1980. Virus infection of endothelial cells increases granulocyte adherence. $J$. Clin. Invest. 65:1469-1477.

47. Iwamoto, G. K., M. M. Monick, B. D. Clark, P. E. Auron, M. F. Stinski, and G. W. Hunninghake. 1990. Modulation of interleukin $1 \beta$ gene expression by the immediate early genes of human cytomegalovirus. J. Clin. Invest. 85:18531857.

48. Fujinami, R. S., J. A. Nelson, L. Walker, and M. B. Oldstone. 1988. Sequence homology and immunologic cross-reactivity of human cytomegalovirus with HLA-DR $\beta$ chain: a means for graft rejection and immunosuppression. J. Virol. 62:100-105.

49. Beck, S., and B. G. Barrell. 1988. Human cytomegalovirus encodes a glycoprotein homologous to MHC class-I antigens. Nature (Lond.). 331:269272.

50. Ross, R. 1986. The pathogenesis of atherosclerosis-an update. N. Engl. J. Med. 314:488-500.

51. Hayflick, L. 1965. The limited lifetime of human diploid cell strains. Exp. Cell. Res. 37:614-636.

52. Ross, R., T. N. Wight, E. Strandness, and B. Thiele. 1984. Human atherosclerosis. I. Cell constitution and characteristics of advanced lesions of the superficial femoral artery. Am. J. Pathol. 114:79-93. 